\title{
Potentials of Biogas and Bioslurry Utilization and Subsidy Incentives Policy Recomendation in Indonesia
}

\author{
Osak REMF ${ }^{1}$, Hartono $\mathrm{B}^{2}$, Fanani $\mathrm{Z}^{2}$, Utami HD ${ }^{2}$ \\ ${ }^{1}$ Faculty of Animal Husbandry, University of Sam Ratulangi, Manado, Indonesia \\ Jl. Kampus, Bahu, Malalayang, Manado, North Sulawesi, Indonesiar \\ ${ }^{2}$ Faculty of Animal Husbandry, University of Brawijaya, Malang, Indonesia \\ Jl. Veteran, Ketawanggede, Lowokwaru, Malang 65145, East Java \\ richard.osak@unsrat.ac.id
}

\begin{abstract}
One of several way reducing greenhouse gases by environmentally friendly development schemes is integrated farming system especially integration of livestock and horticulture. The aimed of this study was to describes the potential of biogas and bioslurry utilization and to provide policy recomendation of them. The research was conducted as a case study in Nongkojajar, East Jawa used the survey method to the sample farmers have dairy cow, horticultural crops, forage plants, and has a biogas reactor installation. The potensials utilization are the contribution in farming system revenue both of biogas and bioslurry are 2.17 and $3.46 \%$. Average biogas production each dairy farmer household about $620.41 \mathrm{~m}^{3} /$ year equivalent to $285.39 \mathrm{~kg} /$ year liquid petroleum gas (LPG). And by used of biogas amount 100,80 kg/year each household, the government can save IDR 589,664/year each household. Utilized bioslurry sale value about IDR $8,685,737.70$ /year/household can give profit to farmer about IDR 1,737,147.54/year/household. Policy recomendation for the development of rural biogas and bioslurry utilization is the grant of incentives to household users to increase the use of biogas and bioslurry, in order to reduce fuels utilization, to reduce environmental impact of livestock farming, and in order Indonesian commitment to support the Sustainable Development Goals (SDGs).
\end{abstract}

Key Words: Biogas-Bioslurry, Subsidy-Incentives, Policy Recomendation

\section{INTRODUCTION}

Sustainable Development Goals in 2030 (SDGs) i.e. end hunger, achieve food security and improved nutrition and promote sustainable agriculture (Goal 3) and ensure access to affordable, reliable, sustainable and modern energy for all (Goal 8). In order SDGs in recent decades, there have been practical innovations in integrated production systems based on conservation agriculture that harness synergies between the production sectors of crops, livestock and agroforestry that ensure economic and ecological sustainability while providing ecosystem services.

FAO's Agriculture and Consumer Protection Department confirmed the importance of the role of integrated crop livestock systems for sustainable development, and that integrated crop-livestock systems, implying a diverse range of integrated ecological, biophysical, socio economic conditions, have been a foundation of agriculture for hundreds of years (FAO 2010). Integrated crop-livestock systems generate and streamline the use of biogas and bio-slurry for environmentally friendly farming.

The future need to promote the integrated crop and livestock systems pattern. IFAD (2009) explained that technologies and management schemes that can enhance productivity need to be developed, at the same time, need to be developed ways or models to preserve the natural resource base. Within this framework, an integrated crop-livestock farming system represents a key solution for enhancing livestock production and safe guarding the environment through prudent and efficient resource use. 
Environmentally friendly livestock development, it should be done through an integrated and sustainable farming systems in order to reduce the effects of the environmental impact caused by livestock, especially ruminants livestock. In recent, integrating crops and/or plantations and livestock serves primarily to minimize risk and not to recycle resources. In an integrated system, crops and/or plantations and livestock interact to create a synergy, with recycling allowing the maximum use of available resources. Crop residues can be used for animal feed, while livestock and livestock byproduct production and processing can enhance agricultural productivity by intensifying nutrients that improve soil fertility, reducing the use of chemical fertilizers.

Devendra (2011) explained that it is important to keep in perspective the terms integration and integrated systems. Integration involves various components, namely crops, animals, land and water. Integrated systems refer to approaches that link the components to economic, social and ecological perspectives. The integration of livestock with trees, food crops and aquaculture is seen as the most appropriate technology to use the natural resources in a system that is productive and sustainable (Preston 2000). Also Hartono \& Rohaeni (2014) reported that cropping patterns in the study area run polyculture or diversification of crops and livestock commodities. The benefit of diversification are to reduce risk of failure and to increase income, employment, and environmental conversion.

One alternative approach to diversify agricultural production is to integrate cash grain cropping with ruminant livestock production. Agriculture including crop production and livestock provides for the food, fodder, and fuel needs in rural regions of many countries. Randall (2003) cited four positive factors associated with livestock being integrated into cropping enterprises: (1) Crops produced on the farm can be used to feed the livestock, thus minimizing the importing of outside feed stuffs in livestock production; (2) Livestock manure can serve as the primary source of nutrients for crop production, thereby cycling nutrients from the crops through the animals and back out on to the land; (3) Livestock can serve as the sink for agricultural by products; and (4) Ruminant livestock encourage the establishment of perennial grass and legume forages as a primary feedstuff.

The possibility of producing food, fodder and biomass fuel in an integrated farming system (IFS) therefore be examined, particularly in developing countries, which are so heavily dependent on agriculture (Ralevic et al. 2012). Preston \& Leng (1989) explained that in a system the processing of the livestock manure by anaerobic digestion is a key component as it has many positive features such as reduction in emission of methane (a major actor in global warming), decrease in pathogens (better health of people and animals), production of biogas for cooking (reduced pressure on forests for fuel wood; more comfortable working conditions in the kitchen for women) and improved nutrient recycling (reduced need for chemical fertilizer).

In rural Southwest Chinese, according to Li (2009) reported that a household biogas system refers to a small-scale energy management scheme that converts animal wastes and farm residues into biogas, an inflammable gas mainly composed of methane $\left(\mathrm{CH}_{4}\right)$. Typically, the system includes an $8-10 \mathrm{~m}^{3}$ concrete anaerobic digester, a latrine, and a pig house. The biogas, generated in the process, provides the household with a fuel for cooking, lighting, and heating. The sludge, after being discharged from the digestion compartment into the displacement tank, is collected as a fertilizer for the fields.

Several studies reported that biogas has a potential to offer significant health, economic, and environmental benefits to most rural households. Biogas can help farmers increase their income by reducing their daily and agricultural expenditures. Biogas system capasity about $8-10 \mathrm{~m}^{3}$ can generate about $550 \mathrm{~m}^{3}$ of biogas per year, which provides enough fuel for cooking and lighting for a family of four or five persons throughout the 
year (Yin et al. 2005). Also, it yields about 15 tons of bioslurry per year, which is a potent fertilizer superior to conventional fertilizers (Brown 2006).

Li (2009) explained that since 1997, the Chinese legislature declared biogas as a national energy development agenda, and the Chinese government subsidies for biogas have been increasing since then. Nevertheless, only about $12 \%$ of rural households utilize biogas. In poor regions, the figure is much lower. At present, biogas counts for merely $1 \% \mathrm{t}$ of energy consumption in rural Chinese.

Livestock farmer in developing countries are commonly poor households that need to be given economic incentives or subsidized. Economic incentives are defined broadly as instruments that use financial means to motivate polluters to reduce the health and environmental risks posed by their facilities, processes, or products (FAO 2001). The extent of community participation, however, depends not only on the incentive structure but also on the social capital that exists in the community. Although Zhuen et al. (2012) indicates that the composition of subsidies has a much smaller effect on efficiency than does the composition of total farm income. And although all incentives give sources of pollution an impetus to minimize their emissions, the incentives take widely differing forms.

The supply of fuels and fertilizer are often irregular, and policies on their use range from taxation to subsidies in various countries. Subsidies can come in many different shapes and sizes depending on the country's institutional endowment and on government policies. Their impact depends not only on the instrument but also on government administrative capability (Barnes \& Halpern, 2000). In fact, the variety of economic incentives in use today is one of the most remarkable developments in environmental management over the past decade (FAO 2001). It is just, according to Zhuen et al. (2012) that the motivation of farmers to work efficiently is lower when they depend to a higher degree on subsidies as a source of income.

Many people in rural areas in Indonesia have limited access to energy sources that are economical and convenient to use. The biogas or processed cow manure also provides opportunities for rural communities to reduce expenses and gain a better income. BIRU (2014b) reported that the BIRU programme started in May 2009 and is targeting the construction of 11,000 domestic biogas digester units in eight provinces in Indonesia. Until the end of 2013, biogas digester built has reached more than 11,000 units, where numbers of digesters produced around 2009-2013 which resulted in 11,249 digesters include in Tutur Nongkojajar District of Pasuruan, East Java.

Current dairy farming in Tutur Nongkojajar is not only to produce fresh milk as primary product, but also able to produce by-products such as organic fertilizer and biogas alternative energy. It seems that the current dairy farming in that site is currently being integrated with horticultural crops in the integrated farming system pattern, so the cycle of dairy cattle farming activities in addition to increasing household income also preserve a sustainable environment.

However, often the use of biogas and biolurry by farmer households in rural areas there are barriers. This study first identifies main barriers to biogas and biolurry in rural areas survey, and then to offer the policy recomendations for decision maker in regional or national development.

\section{MATERIAL AND METHODS}

\section{Location}

The research was conducted in Pasuruan Regency, Province of East Java, Indonesia. In this district has one of sub district that had the largest population of dairy cattle is 
Subdistrict of Tutur Nongkojajar. Selection of the overall study site using multistage sampling method (Table 1), but every level of research conducted in the area by the purposive sampling. This study used research unit are dairy farmers who are members of Dairy Farmers Cooperative KPSP Setia Kawan Nongkojajar as the main research unit.

Table 1. Multistage sampling location

\begin{tabular}{ll}
\hline \hline Stage & Selected locations \\
\hline Regency & Pasuruan \\
Subdistrict & Tutur, Nongkojajar \\
Rural/village & Andonosari, Gendro, Kayubebek, Tlogosari, Tutur, and Wonosari \\
\hline
\end{tabular}

\section{Data collection}

The research was conducted using a survey, where the method of sampling was purposive sampling. Lagares \& Albandoz (2001) explained that purposive sampling is selecting the sample, depending on research purpose. Main criterias of sample respondent according to the research purpose are farmers has dairy cow, horticultural crops, forage plants, and has a biogas reactor installation.

Determination of the number of samples that $>10 \%$ of the total population. Total population of dairy farmer in Subdistrict of Tutur Nongkojajar who have had a biogas reactor installation are 1,220 farmers, so that the number of samples at least 122 farmers. The number of sample villages are six villages, so that each village consists of 20-21 respondent farmers sample. Data for this study consist of primary data and secondary data differ based on the objective of the data collection. The primary data are original and collected by researcher or investigator, in the other hand, the secondary data are collected by using already available sources.

1. Biogas production is the amount of biogas produced $\left(\mathrm{m}^{3} /\right.$ year)

2. Biogas equivalent to LPG is the amount of biogas produced, equivalent to LPG (kg/year)

3. Biogas utilized sale value is the amount of the selling price of the biogas produced, equivalent LPG subsidized (IDR/year)

4. Bioslurry production is the amount of fertilizer (fresh and compost) produced from biogas digester $(\mathrm{kg} / \mathrm{year})$

5. Bioslurry sale value is the amount of the selling price of the bioslurry produced, equivalent fertilizer subsidized (IDR/year)

Method of analysis used is descriptively numerical analysis, which is presented in tabular form.

\section{RESULTS AND DISCUSSION}

Indonesia currently has a biogas and bioslurry development program, it is the Indonesia domestic biogas programme as an initiative of Hivos and SNV. Closely working with the Indonesian Ministry of Energy and Mineral Resources, the programme is implemented by Yayasan Rumah Energi (YRE) with funds made available by EnDev (Energising Development), the Norwegian Embassy and partners in promoting access to a modern and sustainable form of renewable energy for rural people.

The Indonesian Domestic Biogas Programme (IDBP) is in Indonesia better known as the BIRU programme; an acronym of Biogas Rumah, or 'biogas for the home'. BIRU aims 
to promote the use of biodigesters as a local, sustainable, energy source by developing the market while working towards the development of a commercial, market-oriented sector, leading to the creation of jobs. Started in May 2009 with financial support from the Netherlands Embassy and as of November 2015, has built 16,015 biogas digesters in nine provinces in Indonesia (BIRU 2016).

District of Pasuruan is one of districts that choosed for implementation the programme due to as one of the largest milk producing areas in East Java, Indonesia. This district has a subdistrict as a center for dairy farming that is Tutur Nongkojajar. Dairy cow population in this sub district are amount 17.765 heads, with milk production about 63,000 liters per day or 23,523.5 tonnes a year, and with potential production of dairy cattle dung about 20 $\mathrm{kg} / \mathrm{cow} / \mathrm{day}$ have been used biogas through household-scale biogas reactor (Osak 2015).

Reactor technology used in research site is the fixed-dome reactor. The biogas digesters/reactors is an BIRU's adaptation of existing systems used in other countries and function as converters of dairy cattle dung, and possibly human excrement and other organic materials, into combustible biogas. Uses of biogas consumption in households, among othersare to fuel simple gas stoves for cooking and pump lamps for lighting. This fixed-dome reactor is made from masonry and concrete work concealed underground.

The fixed dome biogas plant has a minimum lifetime of 15 years if properly used and maintained. Maintenance is easy, it merely requires the occasional checking and repair of pipes and fittings. To operate one unit, the farmer needs to have at least two cows or seven pigs (or 170 poultry) to produce enough feed for the reactor to be able to generate sufficient gas to meet their daily basic cooking and lighting needs. The system is proven to be environmentally friendly and a clean energy source according to Pranadji et al. (2010) and BIRU (2014a).

Profile of dairy farming in Nongkojajar East Java Indonesia, generally as small scale farmers, traditional dairy farming, kept in the yard of the house with a simple system of housing and equipment. The farmers generally have relatively small field land, cultivated fruits, horticulture crops and forage crops fodder. Crop-livestock integrated farming system (CLS-IFS) or integration system of dairy and plants generally have not been applied, despite the research studies that recommend this integration system. Currently practice in sub district of Tutur Nongkojajar, where the dairy cattle with plants farming only as a mixed pattern farming that almost like CLS-IFS. The study indicated that the highest revenue in dairy-horticulture integrated farming system is dairy cattle farming about $46.54 \%$, while the smallest is utilized biogas sale value about $2.17 \%$.

In the other aspects, forage farm revenue greater than horticulture farm revenue, because most farmer's land is planted forage for support the main farming activities of dairy farming. Only small part of farmer's land was used for horticultural plants like vegetables, fruits tree or flower plants.

Table 2 showed that average biogas production each dairy farmer household about $620.41 \mathrm{~m}^{3} /$ year equivalent to $285.39 \mathrm{~kg}$ liquid petroleum gas (LPG) fuel. This is indicated that the utilization of biogas save the use of LPG, reduce the destruction of forests and environmental impact as a result of cow dung and firewood utilization.

In the other hand, price of LPG subsidized of IDR 5,850/kg and LPG non-subsidized (economic price) of IDR 8,500-9,000/kg in 2014 (Indonesia in 2016 IDR 15.110/kg, is still lower than in some neighboring countries such as India IDR 12.600/kg, Japan IDR $20,000 / \mathrm{kg}$ and China IDR 21,000/kg). Indonesian government through PT Pertamina (State Oil and Natural Gas Mining Company) selling LPG with price subsidized of IDR $5,850.00 / \mathrm{kg}$ at the time of the study in 2014 . Therefore, by used of biogas amount 100,80 $\mathrm{kg}$ per year can save a subsidy about IDR 453/kg can save a subsidy about IDR 453,588503,987 or average IDR 470,387/year. Moreover, LPG economic price (non-subsidized 
price) in Indonesia about IDR $8,500-9,000 / \mathrm{kg}$, by used of biogas amount 100,80 kg/year/ farmer household, the government can save IDR 589,664/year/farmer household.

Table 2. Biogas utilization in dairy-horticulture integrated farming system (IFS)

\begin{tabular}{lrr}
\hline \hline Component & \multicolumn{1}{c}{ Sum } & Average/household \\
\hline Family size (people)* & 501.00 & 4.11 \\
Dairy scale (heads)** & 841.00 & 6.89 \\
\hline Biogas production (m³/year) & $75,690.00$ & 620.41 \\
Biogas equivalent to LPG (kg/year) & $34,817.40$ & 285.39 \\
Biogas utilized equivalent to LPG (kg/year) & $12,297.27$ & 100.80 \\
Biogas non-utilized (kg/year) & $22,520.13$ & 184.59 \\
Biogas utilized value equivalent to LPG non- & $375,505,659.00$ & $3,077,915.24$ \\
subsidized (IDR/year) & & \\
Biogas utilized value equivalent to LPG subsidized & $162,481,200.00$ & $1,331,813.11$ \\
(IDR/year)*** & $132,626,086.36$ & $1,087,099.07$ \\
Biogas utilized sale value (IDR/year) & $41,100,000.00$ & $336,885.25$ \\
Biogas processing cost (IDR/year) & $91,526,086.36$ & $750,213.82$ \\
Profit (net sale value) biogas utilized (IDR/year) & $8,526.00$ & 69.89 \\
\hline Utilized amount of subsidized LPG (kg/year) & $39,788,000.00$ & $326,131.15$ \\
\hline Amount purchase of subsidized LPG(IDR/year) & & \\
\hline
\end{tabular}

*Number of farmers household: 122; **Number of livestock produce biogas 841 heads; ***Price of LPG sibsidized of IDR 5,850/kg and LPG non-subsidized of IDR $8,500-9,000 / \mathrm{kg}$ at the time of the study in 2014 and IDR $15.110 / \mathrm{kg}$ in 2016

Table 3 showed that Bioslurry (fresh and compost) production about 17,371.48 $\mathrm{kg} /$ year each farmer household as subtituted of chemical fertilizers that used in forage and horticulture plants. Utilized bioslurry sale value about IDR 8,685,737.70/year/household can give profit to farmer about IDR 1,737,147.54/year/household. This seemly just a bit contribution, but have environmenly and healthy advantages to improve the balance of soil nutrients and reduce chemistry fertilizer utilization which adversely affects the health of food consumers.

Table 3. Bioslurry utilization in dairy-horticulture integrated farming system (IFS)

\begin{tabular}{lrr}
\hline \hline Component & \multicolumn{1}{c}{ Sum } & Average/household \\
\hline Bioslurry (fresh and compost) production (kg/year) & $2,119,320.00$ & $17,371.48$ \\
Bioslurry sale value (IDR/year) & $1,059,660,000.00$ & $8,685,737.70$ \\
Bioslurry processing cost & $847,728,000.00$ & $6,948,590.16$ \\
Profit (net sale value) bioslurry & $211,932,000.00$ & $1,737,147.54$ \\
\hline
\end{tabular}

Potentials of biogas and bioslurry utilization showed that the contibution of biogas is $2.17 \%$ and bioslurry is $3.46 \%$ in farming system revenue. Contribution of biogas is still a bit in farming revenue, because the barrier is the habits of households using biogas is still unfamiliar or still not accustomed than using firewoods, kerosene or liquid petroleum gas (LPG) fuel. Pranadji et al. (2010) reported that $72,5 \%$ of household had a fairly good perception of LPG fuel than others fuel. 


\section{Incentives policy recomendations}

The Government of Indonesia, like many countries around the world, has used subsidies for decades to promote a range of social and economic objectives. Among the priorities vying for support are poverty alleviation, infrastructure development, health and education. Given the competing demands, deciding where to allocate public financial resources is one of the government's most important and difficult tasks. The government spends more on subsidies to fuel than it does on capital expenditure for public infrastructure, energy subsidies are allocated for 2013 about IDR 194 trillion for fuel and IDR 81 trillion for electricity (Ministry of Finance 2012).

The government of Indonesia reformed kerosene and LPG subsidies. Kerosene is mainly used for household cooking and lighting. In 2007 the government introduced its kerosene-to-LPG conversion program, which further reduced the kerosene subsidies. In 2006, the government budgeted IDR 31.5 trillion (US\$ 3.5 billion) for kerosene subsidies, IDR 36.5 trillion (US\$ 4 billion) in 2007 and IDR 38 trillion (US\$ 3.8 billion) in 2008. Facing fiscal pressure from high kerosene subsidies, the Government of Indonesia started a kerosene-to-LPG conversion program to reduce the kerosene subsidy in 2007. The program provides a free start-up package consisting of a $3 \mathrm{~kg}$ LPG tank, a compact LPG stove and its accessories (regulator and hose). The subsidized price (before tax) for a $3 \mathrm{~kg}$ cylinder tank is IDR 3,500/kg, meaning each kilogram of LPG is subsidized by IDR 3,200. Currently, the selling price after tax is IDR $4,500 / \mathrm{kg}$, so $3 \mathrm{~kg}$ LPG costs about IDR 13, 500/tank (MEMR 2007).

The program called the Indonesian domestic biogas program, or locally known as BIRU (an acronym of biogas rumah or household biogas), aims to distribute domestic biogas digesters as a local and sustainable energy source for households. Implementation of the program is in the hands of Yayasan Rumah Energi (YRE) foundation, with support from the Ministry of Energy and Mineral Resources and the Netherlands government. The program started in 2009 in nine provinces nationwide, including Subdistric of Tutur Nongkojajar.

In the early phase of the program, some households joined the program through a selffinancing scheme. Installing the digesters costs IDR 7.5 million (US\$ 774) per household. They also get technical assistance from YRE's local partners in each regency. However, since not all households can afford it, the foundation works together with local administrations in its regency to provide subsidies, so the households get the facility under a cost-sharing system and some have even provided full subsidies. The foundation will also encourage cooperatives in villages to provide credit schemes to support more households to join this program.

Osorio et al. (2011) reported that in Indonesia, most farmers benefit from fertilizer subsidies; however, the $40 \%$ largest farmers capture up to $60 \%$ of the subsidy. The regressive nature of the fertilizer subsidies is in line with research carried out in other countries, the result of larger farms using a larger volume of fertilizer. Budget allocation for food fertilizer subsidy 2013 was set at IDR 25.9 trillion $(0.2 \%$ against GDP) rising by IDR 2.0 trillion against fertilizer subsidy ceiling set in APBN-P State Budget 2012 of IDR 13.9 trillion (0.2\% against GDP). Allocation for fertilizer subsidy in 2013 was inclusive of compensation of underpaid subsidy of 2010 amounting to IDR 84.2 billion.

After the installation of biogas systems in operation, the household began to experience barriers such as spent time to insert dung (manure) to digester every day, in addition the entry of an LPG subsidies program, that very practical and is not more fouled cookers tool, and more familiar than biogas. So in addition to subsidizing the installation 
of the digester system costs, also required the transfer of LPG subsidy to biogas subsidy, for the aims to stimulate increasing interest of household in the utilizaton of biogas.

To excite or motivate households to use biogas and bioslurry that they produce, then the government both central and local government should provide incentive or subsidize policy for the use of biogas and bioslurry. Policy recomendation for the development of rural biogas and bioslurry is the grant of incentives to users household for to increase the use of biogas and bioslurry, in order to reduce environmental impact of livestock farming, and in order Indonesian commitment to support the Sustainable Development Goals (SDGs).

\section{CONCLUSION}

Contribution and utilization of biogas is still a bit, because the habits of households using biogas is still unfamiliar or still not accustomed than using firewood, kerosene or LPG fuel. Average biogas production each dairy farmer household about $620.41 \mathrm{~m}^{3} /$ year equivalent to $285.39 \mathrm{~kg}$ LPG. And by used of biogas amount $100,80 \mathrm{~kg} /$ year/farmer household, the government can save IDR 589,664/year each farmer household. Likewise, utilized bioslurry sale value about IDR 8,685,737.70/year/household can give profit to farmer about IDR 1,737,147.54/year/household. To excite or motivate farmer households to use biogas and bioslurry that they produce, then the government should subsidize or provide incentive policy for the use of biogas and organic fertilizer, in order to reduce environmental impact of livestock farming and and in order Indonesian commitment to support the Sustainable Development Goals (SDGs).

\section{Suggestions}

Research needed to generate knowledge and innovative practices to underpin farmer adoption and scaling of promising crop-livestock systems for sustainable production intensification. Political will, and policy and institutional support for the adoption and enabling the spread of innovations and practices associated with promising crop-livestock systems for environment friendly, especially the most important thing in biogas and bioslurry utilization is that it is included the national policy and continuously supported by the government.

\section{REFERENCES}

Barnes DF, Halpern J. 2000. Subsidies and sustainable rural energy services: Can we create incentives without distorting markets. Washington DC (US): The International Bank for Reconstruction and Development, The World Bank.

BIRU. 2014a. Bio-slurry extension. http://www.biru.or.id/en/index.php/bio-slurry/

BIRU. 2014b. BIRU Digester. http://www.biru.or.id/en/index.php/digester/

BIRU. 2016. BIRU Program. http://www.biru.or.id/en/index.php/biru-program/

Brown VJ. 2006. Biogas: A bright idea for Africa. Environ Health Perspect. 114:A300-A303.

Devendra C. 2011. Integrated tree crops-ruminants systems in South East Asia: Advances in productivity enhancement and environmental sustainability. Asian Australas J Anim Sci. 24:587-602.

FAO. 2001. Mixed crop-livestock farming: A review of traditional technologies based on literature and field experience. Animal Production and Health Papers 152. Rome (Italy): FAO. 
FAO. 2010. Sete Lagaos "consensus" on integrated crop-livestock-tree systems form sustainable development (IC-LSD). An international consultation on integrated crop-livestock systems for development-The way forward for sustainable production intensification. Integrated Crop Management. 13:2010.

Hartono B, Rohaeni ES. 2014. Contribution to income of traditional beef cattle farmer households in Tanah Laut Regency, South Kalimantan, Indonesia. Livest Res Rur Dev. 26:2014.

IFAD. 2009. Integrated crop-livestock farming systems. Rome (Italy): IFAD Headquarters.

Lagares BP, Albandoz JP. 2001. Population and sample. Sampling techniques, management mathematics for european schools http//optimierung.mathematik.unikl.de/mamaeusch/ veroeffentlichungen/ver_texte/sampling_en.pdf

Li J. 2009. Socioeconomic barriers to biogas development in rural Southwest China: An ethnographic case study. Hum Organ. 68:415-430.

Ministry of Finance RI. 2012. Nota keuangan dan rancangan anggaran pendapatan dan belanja negara tahun anggaran 2013. Jakarta (Indonesia): Ministry of Finance of the Government of Indonesia.

MEMR. 2007. Blueprint program pengalihan minyak tanah ke LPG. Jakarta (Indonesia): Ministry of Energy and Mineral Resources of the Government of Indonesia.

Osak REMF, Hartono B, Fanani Z, Utami HD. 2015. Biogas and bioslurry utilization on dairyhorticulture integrated farming system in Tutur Nongkojajar, District of Pasuruan, East Java, Indonesia. Livest Res Rur Dev. 27:2015.

Osorio CG, Abriningrum DE, Armas EB, Firdaus M. 2011. Who is benefiting from fertilizer subsidies in Indonesia? Policy research working paper 5758. East Asia and Pacific Region, Poverty Reduction and Economic Management Unit. Washington DC (US): The World Bank.

Pranadji DK, Djamaludin MD, Kiftiah N. 2010. Behaviour analysis of using the household fuel in Bogor City. J Ilmu Keluarga Konsumen. 3:173-183.

Preston TR. 2000. Livestock production from local resources in an integrated farming system: A sustainable alternative for the benefit of small scale farmers and the environment. In: Preston TR, Ogle RB, editors. Workshop-Seminar Making Better Use of Local Feed Resources SAREC-UAF.

Preston TR, Leng RA. 1989. The greenhouse effect and its implications for world agriculture. The need for environmentally friendly development. Livest Res Rur Dev. 1:1989

Ralevic P, Patil SG, vanLoon G. 2012. Integrated agriculture production systems for meeting household food, fodder and fuel security. J Sustain Agric. 34:878-906.

Randall GW. 2003. Present-day agriculture in southern Minnesota-is it sustainable? Minnesota (US): University of Minnesota, Southern Research and Outreach Center.

Yin Z, Liu L, Cao A. 2005. Analysis on the role of biogas in cycling economy in agriculture in less developed areas. Agric Environ Dev. 6:1-4.

Zhuen X, Demeter RM, Lansink AO. 2012. Technical efficiency and productivity differentials of dairy farms in three EU countries: The role of CAP subsidies. Agric Eco Rev. 13:66-92. 